\title{
Recent advances in understanding/management of non-alcoholic steatohepatitis
}

\author{
Tommy Pacana and Arun J. Sanyal*
}

\author{
Address: Division of Gastroenterology, Hepatology and Nutrition, Department of Internal Medicine, Virginia Commonwealth University School \\ of Medicine, Richmond, VA 23298, USA \\ *Corresponding author: Arun J. Sanyal (asanyal@mcvh-vcu.edu) \\ Fl000Prime Reports 2015, 7:28 (doi:10.12703/P7-28) \\ All FI000Prime Reports articles are distributed under the terms of the Creative Commons Attribution-Non Commercial License \\ (http://creativecommons.org/licenses/by-nc/3.0/legalcode), which permits non-commercial use, distribution, and reproduction in any medium, \\ provided the original work is properly cited. \\ The electronic version of this article is the complete one and can be found at: http://fl $000 . c o m / p r i m e / r e p o r t s / m / 7 / 28$
}

\begin{abstract}
Non-alcoholic steatohepatitis (NASH) can lead to advanced fibrosis, hepatocellular carcinoma, and end-stage liver disease requiring liver transplantation. A myriad of pathways and genetic influence contribute to NASH pathogenesis and liver disease progression. Diagnosing patients with NASH and advanced fibrosis is critical prior to treatment and prognostication. There has been ongoing interest in developing non-invasive biomarkers and tools for identifying NASH and advanced fibrosis. To date, there has been no approved therapy for NASH. Recently, the FLINT (Farnesoid X Receptor [FXR] Ligand Obeticholic Acid in NASH Treatment) trial provided promising results of the efficacy of obeticholic acid, a farnesoid X receptor agonist, in improving histological features of NASH and fibrosis. Long-term studies are needed to assess the safety of obeticholic acid and its effects on liver- and cardiovascular-related outcomes.
\end{abstract}

\section{Introduction}

Non-alcoholic fatty liver disease (NAFLD) is the most common chronic liver disease in North America and has emerged as a serious public health burden. The clinical-histological phenotype of NAFLD extends from non-alcoholic fatty liver (NAFL) to NASH. The estimated worldwide pre-valences of NAFLD and NASH range from $6.3 \%-33 \%$ and $3 \%-5 \%$, respectively $[1,2]$. Whereas NAFL can progress to cirrhosis in $2 \%$ to $3 \%$, $\mathrm{NASH}$ has an increased risk for the progression to cirrhosis at $15 \%$ to $20 \%$ and predisposes patients to the development of hepatocellular carcinoma and increased mortality $[3,4]$. Although extensive research in understanding the disease pathogenesis and numerous clinical trials aimed at halting disease progression have been performed in the last two decades, optimal therapy is still lacking. The aims of this article are to provide a short overview of important mechanisms and genetic factors influencing NAFLD disease progression and to present strategies in the diagnostic and therapeutic management of NASH.

\section{Pathogenesis of non-alcoholic steatohepatitis}

The histological hallmark of NAFLD is hepatic steatosis. Dysfunctional adipocytes secrete cytokines and chemokines, and this perpetuating inflammatory cycle induces a state of insulin resistance, resulting in failure to suppress lipolysis in the adipocytes [5]. This leads to release of free fatty acids (FFAs) to the circulation and is followed by uptake of these FFAs to the liver. A carbohydrate-rich diet and hyperinsulinemia activate carbohydrate-related element-binding protein (ChREBP) and sterol regulatory element-binding protein-1 (SREBP-1), respectively, and promote hepatic de novo lipogenesis [6]. The imbalance between triglyceride acquisition and removal results in excess triglycerides stored as lipid droplets.

Several mechanisms have been implicated in the progression from steatosis to NASH. Key players include lipotoxicity, oxidative stress, endoplasmic reticulum (ER) stress, activation of the innate immune activity, and cytokinemediated cellular damage. It has been demonstrated that triglyceride synthesis is not harmful but protective against 
fatty acid-induced lipotoxicity [7]. It is known that FFAs can directly activate inflammatory pathways, ER stress, and the innate immune system via Toll-like receptors [8]. Recently, many aspects of lipid metabolism were reported to be altered in NAFLD [9]. The presence of biologically active lipid molecules such as free cholesterol, diacylglycerol, lysophosphatidylcholine, and ceramides can affect lipogenesis, insulin signaling, and cellular injury and contribute to NAFLD phenotype and disease progression [10-12]. Once the capacity of the liver to store triglycerides is overwhelmed, there is increased compensation by the mitochondria and peroxisomes to oxidize fatty acids. The oxidative capacity of these organelles becomes impaired and can lead to overproduction of reactive oxygen species [13]. The consequent cytokine production and lipid peroxidation have the potential to induce apoptosis, inflammation, and liver fibrosis. In response to ER stress, the unfolded protein response is activated to restore homeostasis as an adaptive mechanism [14]. However, pathways leading to apoptosis are initiated if homeostasis is compromised. Moreover, the gut microbiome has been more recognized to play an important role in the pathogenesis of NASH. Changes in the microbiota can alter intestinal permeability and promote translocation of microbes into the portal circulation. The gut-derived microbial products, including lipopolysaccharide and bacterial DNA, can enter the liver and induce inflammation by activating Toll-like receptors in Kupffer cells and hepatocytes [15]. In addition, the innate immune system is activated in the adipocytes, and the release of various adipokines (interleukin- 6 and tumor necrosis factor-alpha) can contribute to hepatic inflammation [16]. Combined with the host genetic background, the complex interplay of these mechanisms can produce inflammation, hepatocellular injury, and cell death and activate fibrogenesis.

\section{Genetic variants in non-alcoholic fatty liver disease}

Phenotypic variations in NAFLD with similar risk factors implicate a genetic contribution. The genetic susceptibility was first demonstrated by the first genome-wide association study (GWAS) on NAFLD in a population of Hispanic, African American, and European American individuals [17]. Variations in palatin-like phospholipase domain-containing 3 (PNPLA3) were shown to influence ancestry-related and inter-individual difference in hepatic fat content and susceptibility to NAFLD. Specifically, the allele rs738409 encoding for the isoleucine-to-methionine variant at protein position 148 (I148M) was strongly linked to hepatic fat accumulation and inflammation. This finding was replicated in several studies across different populations and found to be associated with NAFLD disease severity [18-24].
Through a similar GWAS strategy, other single-nucleotide polymorphisms (SNPs) were identified and associated with various aspects of NAFLD phenotype [25]. Variants near PNPLA3, neurocan (NCAN), and protein phosphatase 1, regulatory (inhibitor) subunit 3B (PPP1R3B) were associated with computed tomography-measured hepatic steatosis from several large-population studies. These SNPs were subsequently genotyped in biopsy-proven NAFLD from the NASH Clinical Research Network and showed that variants in or near NCAN, glucokinase regulator (GCKR), lysophospholipase-like 1 (LYPLAL1), and PNPLA3, but not PPP1R3B, were associated with histologic lobular inflammation or fibrosis or both. These variants have distinct effects on various metabolic pathways indicative of genetic heterogeneity in NAFLD pathogenesis. More recently, Kozlitina and colleagues [26] reported the association of a transmembrane 6 superfamily member 2 (TM6SF2) variant with hepatic triglyceride content in an exome-wide association study of patients derived from the Dallas Heart Study. The gene is more common in individuals of European ancestry (7.2\%) than in African Americans (3.4\%) or Hispanics (4.7\%). The TM6SF2 variant encoding p.Glu167Lys correlated with elevated serum alanine aminotransferase (ALT) and reductions in serum alkaline phosphatase and plasma levels of triglycerides and low-density lipoprotein cholesterol in three large cohorts. Although the exact function of the gene is unknown, it has been proposed that the TM6SF2 acts to promote very-low-density lipoprotein secretion. In another study, the TM6SF2 rs58542926 was found to be associated with NASH severity and advanced liver fibrosis [27].

\section{Diagnosis}

Whereas NAFL is characterized by the presence of hepatic steatosis with no evidence of hepatocellular injury, NASH is characterized histologically by the presence of ballooned hepatocytes and lobular inflammation with or without perisinusoidal fibrosis in addition to steatosis [28]. Diagnosing NASH and advanced fibrosis is crucial for prognostication and before starting therapy. Although liver biopsy is considered the gold standard to diagnose and stage NASH, it is invasive and has several limitations, including cost and sampling error, and is accompanied by risks (bleeding, pain, perforation, infection, and rarely death) $[29,30]$. The metabolic syndrome and diabetes are associated with increased risk for NASH and can be used in selecting those patients for liver biopsy $[31,32]$. The levels of aminotransferases are not reliable, and imaging studies have not been accurate in the diagnosis of NASH and this is because the histologic features of apoptosis, ballooning, and cell injury that characterize NASH are not detectable by currently available modalities. 
The poor performance of liver biopsy has led to significant interest in developing non-invasive biomarkers for identifying steatohepatitis or fibrosis (or both) in patients with NAFLD. Multiple biomarkers and predictive models have been suggested to predict NASH but with varying degrees of success, and the majority require external validation [33]. Circulating keratin 18 (CK18), a marker for hepatocyte apoptosis, is the most validated biomarker that is reproduced in several studies for differentiating NASH from simple steatosis [34-37]. In a recent meta-analysis, plasma CK18 levels had a sensitivity of $78 \%$, specificity of $87 \%$, and an area under the receiver operating curve (AUROC) of 0.82 for identifying steatohepatitis. Though fairly specific, this biomarker lacks the sensitivity needed for it to be an adequate screening test to stage NASH [38].

The NAFLD fibrosis score and enhanced liver fibrosis (ELF) panel are non-invasive tools that facilitate the identification of the majority of advanced fibrosis patients but without the need of a liver biopsy [28]. The NAFLD fibrosis score is a scoring tool calculated by incorporating clinical parameters that include age, glycemia, body mass index, platelet count, albumin, and aspartate transaminase-to-ALT ratio. This has been validated in many studies and confirmed by a recent metaanalysis to predict advanced fibrosis with an AUROC of 0.85 [39]. The ELF combines three serum markers of matrix turnover (TIMP 1, hyaluronic acid, and P3NP) and can identify advanced fibrosis in NASH patients with an AUROC of 0.87 [40]. However, both NAFLD fibrosis score and ELF perform poorly in early and intermediate stages.

Modalities that measure liver stiffness were developed to assess liver fibrosis. Transient elastography (FibroScan ${ }^{\circledR}$ ) was first evaluated in a Japanese study that reported a stepwise increase in liver stiffness with increased severity of liver fibrosis [41]. A meta-analysis showed a pooled AUROC of 0.94 with 94\% sensitivity and 95\% specificity for advanced fibrosis [39]. A major drawback of this modality is its inconsistency in obtaining measurements in obese patients [42]. Using a new XL probe has enabled the examination in obese patients with diagnostic accuracy comparable to that of the standard probe [43]. More recently, studies have shown promise of acoustic radiation force impulse (ARFI) sonoelastography for the assessment of liver stiffness [44-46]. Aside from having the capability to be integrated in a standard liver ultrasound, this modality can evaluate large parts of the liver in one examination and is more reliable than transient elastography in obese patients. In a study of 57 patients with NAFLD, ARFI showed a diagnostic accuracy similar to that of transient elastography for advanced fibrosis when compared with liver histology [45]. A recent meta-analysis of various chronic liver diseases confirmed this finding, although only a small proportion of patients were in the NAFLD group [47]. Therefore, more studies are needed to validate this modality in NAFLD. Another imaging modality is magnetic resonance elastography, which allows evaluation of the whole liver and shows good accuracy for detecting severity of liver fibrosis [48]. Its major limitations are cost and lack of wide availability. More studies are needed to assess the role of these imaging tools in assessing changes in fibrosis in response to treatment.

\section{Treatment}

Meaningful therapy for NASH should target reduction of mortality, development of metabolic comorbidities, liver-related and cardiovascular outcomes, and improvement of symptoms and quality of life. Despite an increasing understanding of the mechanisms of NAFLD pathogenesis, approved therapy is lacking.

Lifestyle modifications (diet and regular exercise) remain the initial therapeutic strategy for NASH. This simple yet challenging approach has been shown to correlate with NASH improvement histologically [49-51]. The majority of the patients with NASH have concurrent metabolic comorbidities, and not surprisingly the leading cause of their mortality is cardiovascular disease [52]. The presence of multiple features of the metabolic syndrome is associated with progressive liver disease [53]. Therefore, regardless of NASH diagnosis by liver biopsy, the treatment of obesity, diabetes, dyslipidemia, and hypertension should be optimized in NAFLD to reduce the risks for cardiovascular disease and liver disease progression.

Pharmacologic therapy can be considered only in patients with biopsy-proven NASH until reliable biomarkers are available. Insulin sensitizers, angiotensinconverting enzyme inhibitors and receptor blockers, anti-oxidants, bile acids, cytokine-mediated therapy, lipid-lowering agents, and endocannabinoid antagonists have been proposed, but the majority of these agents either lack efficacy or require further studies for validation before definitive recommendations can be made [54]. This article will focus on pharmacologic options for which sufficient evidence is available to make a recommendation.

Oxidative stress is a major player in the genesis of NASH. Vitamin $\mathrm{E}$ is an antioxidant that suppresses lipid peroxidation, helps replete glutathione stores, decreases 
cytokine production, and inhibits profibrotic activity [55-58]. To date, the Pioglitazone versus Vitamin E versus Placebo for the Treatment of Nondiabetic Patients with Nonalcoholic Steatohepatitis (PIVENS) trial is the largest randomized controlled trial comparing vitamin $\mathrm{E}$ (800 IU/day) and pioglitazone $(30 \mathrm{mg} /$ day) with placebo for 96 weeks in non-diabetic and non-cirrhotic adult patients with NASH [59]. Vitamin E was superior to placebo in improving NASH histology, but no significant improvement in fibrosis was observed. There are insufficient data to recommend vitamin E for NASH patients with concomitant diabetes or cirrhosis, and long-term efficacy and safety of vitamin E remain uncertain. It is important to note that vitamin $\mathrm{E}$ at high doses has been implicated in increased all-cause mortality [60]. Other safety concerns of vitamin $\mathrm{E}$ include increased risk for development of hemorrhagic stroke and prostate cancer $[61,62]$. Therefore, competing risks should be discussed with non-diabetic patients with NASH before starting on therapy.

Thiazolidinediones (TZDs) are peroxisome proliferatoractivated receptor-gamma agonists that ameliorate insulin resistance in adipose tissues, liver, and muscles. TZD increases adiponectin, reduces fatty acid synthesis, and increases fatty acid oxidation by activating $5^{\prime}$ adenosine monophosphate-activated protein kinase (AMPK) and counteracts pro-inflammatory cytokines $[6,63,64]$. Belfort and colleagues [65] showed that pioglitazone improved liver histology by improving steatosis, inflammation, and ballooning in patients with NASH who have impaired glucose tolerance or diabetes. In the largest clinical trial (PIVENS), although pioglitazone did not achieve the primary endpoint as assessed by the NAFLD activity score (NAS), resolution of NASH was achieved in a higher percentage of non-diabetic patients receiving pioglitazone versus placebo ( $47 \%$ versus $21 \%, P=0.001)$ [59]. A recent meta-analysis suggested that pioglitazone may improve liver histology and fibrosis in patients with NASH [66]. In terms of safety, treatment with pioglitazone may not be without adverse effects, and its long-term use has not been studied. Potential adverse effects include weight gain, higher rate of heart failure, bone loss, and rarely bladder cancer [67-70]. Overall, pioglitazone is an option in patients with biopsy-proven NASH, particularly for those with impaired glucose tolerance or diabetes, but this medication must be used with caution.

Obeticholic acid is a synthetic FXR agonist that has been demonstrated to decrease hepatic fat and fibrosis in animal models of NAFLD [71-73]. The potential mechanisms of FXR agonists are represented in Figure 1. More recently, Neuschwander-Tetri and colleagues [74] performed a placebo-controlled, randomized clinical trial (FLINT) that
Figure I. Potential mechanisms of farnesoid $X$ receptor agonists in non-alcoholic steatohepatitis

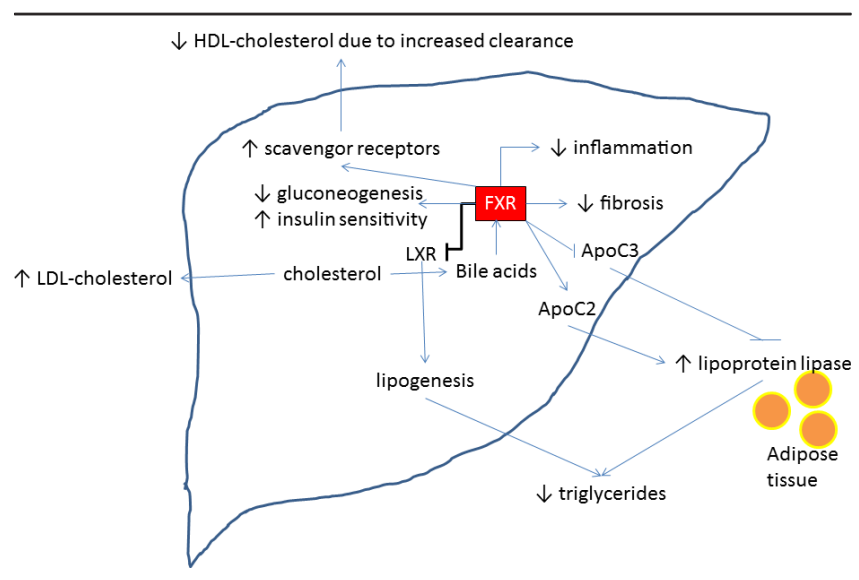

APO C2, apolipoprotein C2; APO C3, apolipoprotein C3; FXR, farnesoid X receptor; LDL-cholesterol, low-density lipoprotein cholesterol; HDLcholesterol, high-density lipoprotein; LXR, liver $X$ receptor.

assessed the efficacy of obeticholic acid ( $25 \mathrm{mg} /$ day) versus placebo for 72 weeks in patients with non-cirrhotic NASH. The primary outcome was improvement in liver histology, defined as a decrease in NAS by at least 2 points without worsening of fibrosis from baseline to the end of treatment. Treatment with obeticholic acid improved all features of the NAS (steatosis, hepatocellular ballooning, and lobular inflammation) and fibrosis. However, complete resolution of NASH was not achieved in a substantial proportion of patients. Although obeticholic acid was generally well tolerated, it was associated with frequent pruritus, increased serum cholesterol, and changes in the lipid profile. Therefore, long-term studies are needed to assess the potential risk of obeticholic acid for the development of atherosclerosis and cardiovascular disease in these patients.

\section{Conclusions}

A better understanding of NASH pathogenesis may help clarify the best approach in managing patients with NASH. More studies are warranted in understanding the influence of genetics associated with disease progression and patient response to treatment. Although liver biopsy is still required, biomarkers to diagnose NASH and tools to predict advanced fibrosis may be helpful, but more studies are needed to validate their use. While obeticholic acid has shown promise in NASH by improving not only liver histology but also fibrosis, not achieved by either vitamin $\mathrm{E}$ or pioglitazone, long-term studies are needed to assess the safety of obeticholic acid and its effects on liverand cardiovascular-related outcomes. The multiplicity of pathways contributing to NASH and fibrosis progression provides a rationale for individualized treatment strategies. 
Combination therapy is an option, but large-scale studies are eagerly awaited.

\section{Abbreviations}

ALT, alanine aminotransferase; ARFI, acoustic radiation force impulse; AUROC, area under the receiver operating curve; CK18, circulating keratin 18; ELF, enhanced liver fibrosis; ER, endoplasmic reticulum; FFA, free fatty acid; FLINT, Farnesoid X Receptor (FXR) Ligand Obeticholic Acid in NASH Treatment; FXR, farnesoid X receptor; GWAS, genome-wide association study; NAFL, nonalcoholic fatty liver; NAFLD, non-alcoholic fatty liver disease; NAS, non-alcoholic fatty liver disease activity score; NASH, non-alcoholic steatohepatitis; NCAN, neurocan; PIVENS, Pioglitazone versus Vitamin E versus Placebo for the Treatment of Nondiabetic Patients with Nonalcoholic Steatohepatitis; PNPLA3, palatin-like phospholipase domain-containing 3; PPP1R3B, protein phosphatase 1, regulatory (inhibitor) subunit 3B; SNP, single-nucleotide polymorphism; TM6SF2, transmembrane 6 superfamily member 2; TZD, thiazolidinedione.

\section{Disclosures}

Arun J. Sanyal is a consulting advisor for Abbot, Genetech, Gilead Sciences, Ikaria, Merck, Norgine, Roche, Salix, Takeda Pharmaceutical Company, Nimbus, Nitto Denko and Bristol-Myers Squibb, receives research grants from Ikaria, Takeda Pharmaceutical Company, Astellas, Novartis and Galectin Therapeutics and receives royalties from Uptodate Inc. Tommy Y. Pacana has no disclosures.

\section{References}

I. Vernon G, Baranova A, Younossi ZM: Systematic review: the epidemiology and natural history of non-alcoholic fatty liver disease and non-alcoholic steatohepatitis in adults. Aliment Pharmacol Ther 20II, 34:274-85.

2. Williams CD, Stengel J, Asike MI, Torres DM, Shaw J, Contreras M, Landt CL, Harrison SA: Prevalence of nonalcoholic fatty liver disease and nonalcoholic steatohepatitis among a largely middle-aged population utilizing ultrasound and liver biopsy: a prospective study. Gastroenterology 20 I, 140: 124-3I.

3. Adams LA, Lymp JF, St Sauver J, Sanderson SO, Lindor KD, Feldstein A, Angulo $P$ : The natural history of nonalcoholic fatty liver disease: a population-based cohort study. Gastroenterology 2005, I29:| |3-2|.

4. Ekstedt M, Franzen LE, Mathiesen UL, Thorelius L, Holmqvist M, Bodemar G, Kechagias S: Long-term follow-up of patients with NAFLD and elevated liver enzymes. Hepatology 2006, 44:865-73.

5. Cusi K: Role of obesity and lipotoxicity in the development of nonalcoholic steatohepatitis: pathophysiology and clinical implications. Gastroenterology 2012, 142:71 I-725 e716.

6. Browning JD, Horton JD: Molecular mediators of hepatic steatosis and liver injury. J Clin Invest 2004, I I 4: 147-52.

7. Yamaguchi K, Yang L, McCall S, Huang J, Yu XX, Pandey SK, Bhanot S, Monia $\mathrm{BP}, \mathrm{Li} Y \mathrm{Y}$, Diehl AM: Inhibiting triglyceride synthesis improves hepatic steatosis but exacerbates liver damage and fibrosis in obese mice with nonalcoholic steatohepatitis. Hepatology 2007, 45: 1366-74.
8. Fuchs M, Sanyal AJ: Lipotoxicity in NASH.J Hepatol 20I2, 56:29I-3.

9. Puri P, Baillie RA, Wiest MM, Mirshahi F, Choudhury J, Cheung O, Sargeant C, Contos MJ, Sanyal AJ: A lipidomic analysis of nonalcoholic fatty liver disease. Hepatology 2007, 46: $1081-90$.

10. Pagadala M, Kasumov T, McCullough AJ, Zein NN, Kirwan JP: Role of ceramides in nonalcoholic fatty liver disease. Trends Endocrinol Metab 20I2, 23:365-7I.

II. Neuschwander-Tetri BA: Hepatic lipotoxicity and the pathogenesis of nonalcoholic steatohepatitis: the central role of nontriglyceride fatty acid metabolites. Hepatology 2010, 52:774-88.

12. Kakisaka K, Cazanave SC, Fingas CD, Guicciardi ME, Bronk SF, Werneburg NW, Mott JL, Gores GJ: Mechanisms of lysophosphatidylcholine-induced hepatocyte lipoapoptosis. Am J Physiol Gastrointest Liver Physiol 2012, 302:G77-84.

13. Koek GH, Liedorp PR, Bast $A$ : The role of oxidative stress in nonalcoholic steatohepatitis. Clin Chim Acta 20I I, 4I 2: I297-305.

14. Kapoor A, Sanyal AJ: Endoplasmic reticulum stress and the unfolded protein response. Clin Liver Dis 2009, I3:58I-90.

15. Miele L, Marrone G, Lauritano C, Cefalo C, Gasbarrini A, Day C, Grieco A: Gut-liver axis and microbiota in NAFLD: insight pathophysiology for novel therapeutic target. Curr Pharm Des 2013, 19:5314-24.

16. Meli R, Mattace Raso G, Calignano A: Role of innate immune response in non-alcoholic Fatty liver disease: metabolic complications and therapeutic tools. Front Immunol 20I4, 5:I77.

17. Romeo S, Kozlitina J, Xing C, Pertsemlidis A, Cox D, Pennacchio LA, Boerwinkle E, Cohen JC, Hobbs HH: Genetic variation in PNPLA3 confers susceptibility to nonalcoholic fatty liver disease. Nature Genet 2008, 40: |46I-5.

\section{FlOOOPrime}

RECOMMENDED

18. Sookoian S, Castano GO, Burgueno AL, Gianotti TF, Rosselli MS, Pirola $\mathrm{CJ}$ : A nonsynonymous gene variant in the adiponutrin gene is associated with nonalcoholic fatty liver disease severity. J Lipid Res 2009, 50:2 III-6.

19. Sookoian S, Pirola C]: Meta-analysis of the influence of II48M variant of patatin-like phospholipase domain containing 3 gene (PNPLA3) on the susceptibility and histological severity of nonalcoholic fatty liver disease. Hepatology 20II, 53:1883-94.

20. Palmer ND, Musani SK, Yerges-Armstrong LM, Feitosa MF, Bielak LF, Hernaez R, Kahali B, Carr JJ, Harris TB, Jhun MA Kardia SL, Langefeld CD, Mosley TH Jr, Norris JM, Smith AV, Taylor HA, Wagenknecht LE, Liu J, Borecki IB, Peyser PA, Speliotes EK: Characterization of European ancestry nonalcoholic fatty liver disease-associated variants in individuals of African and Hispanic descent. Hepatology 20I3, 58:966-75.

21. Baulande $\mathrm{S}$ : [Polymorphisms in adiponutrin gene and association to hepatic steatosis]. Med Sci (Paris) 2009, 25: I30-2.

22. Johansson LE, Lindblad U, Larsson CA, Rastam L, Ridderstrale M: Polymorphisms in the adiponutrin gene are associated with increased insulin secretion and obesity. Eur J Endocrinol 2008, I 59:577-83.

23. Kotronen A, Peltonen M, Hakkarainen A, Sevastianova K, Bergholm R, Johansson LM, Lundbom N, Rissanen A, Ridderstrale M, Groop L, Orho-Melander M, Yki-järvinen H: Prediction of non-alcoholic fatty liver disease and liver fat using metabolic and genetic factors. Gastroenterology 2009, 137:865-72.

24. Kawaguchi T, Sumida $Y$, Umemura A, Matsuo K, Takahashi M, Takamura T, Yasui K, Saibara T, Hashimoto E, Kawanaka M, Watanabe S, Kawata S, Imai $Y$, Kokubo M, Shima T, Park H, Tanaka H, Tajima K, Yamada R, Matsuda F; Takeshi Okanoue, Japan Study Group of Nonalcoholic Fatty Liver Disease: Genetic polymorphisms of the human PNPLA3 gene are strongly associated with severity of non-alcoholic fatty liver disease in Japanese. PloS One 2012, 7:e38322.

25. Speliotes EK, Yerges-Armstrong LM, Wu J, Hernaez R, Kim LJ, Palmer CD, Gudnason V, Eiriksdottir G, Garcia ME, Launer LJ, Nalls MA, Clark JM, Mitchell BD, Shuldiner AR, Butler JL, Tomas M, Hoffmann U, Hwang SJ, Massaro JM, O'Donnell CJ, Sahani DV, 
Salomaa V, Schadt EE, Schwartz SM, Siscovick DS; NASH CRN; GIANT Consortium; MAGIC Investigators, Voight BF, Carr JJ, Feitosa MF, Harris TB, Fox CS, Smith AV, Kao WH, Hirschhorn JN, Borecki IB; GOLD Consortium: Genome-wide association analysis identifies variants associated with nonalcoholic fatty liver disease that have distinct effects on metabolic traits. PLoS Genet 20II, 7: el00I324.

\section{FlOOOPrime}

26. Kozlitina J, Smagris E, Stender S, Nordestgaard BG, Zhou HH, Tybjaerg-Hansen A, Vogt TF, Hobbs HH, Cohen JC: Exome-wide association study identifies a TM6SF2 variant that confers susceptibility to nonalcoholic fatty liver disease. Nat Genet 20I4, 46:352-6.

FlOOOPrime RECOMMENDED

27. Liu YL, Reeves HL, Burt AD, Tiniakos D, McPherson S, Leathart JB, Allison ME, Alexander GJ, Piguet AC, Anty R, Donaldson P, Aithal GP, Francque S, Van Gaal L, Clement K, Ratziu V, Dufour JF, Day CP, Daly AK, Anstee QM: TM6SF2 rs58542926 influences hepatic fibrosis progression in patients with non-alcoholic fatty liver disease. Nat Commun 20 I4, 5:4309.

\section{FlOOOPrime}

\section{RECOMMENDED}

28. Chalasani N, Younossi Z, Lavine JE, Diehl AM, Brunt EM, Cusi K, Charlton M, Sanyal AJ: The diagnosis and management of nonalcoholic fatty liver disease: practice Guideline by the American Association for the Study of Liver Diseases, American College of Gastroenterology, and the American Gastroenterological Association. Hepatology 2012, 55:2005-23. - Guidelines by AASLD in NAFLD diagnosis and management.

29. Bravo AA, Sheth SG, Chopra S: Liver biopsy. N Engl J Med 200I, 344:495-500.

\section{FlOOOPrime}

30. Merriman RB, Ferrell LD, Patti MG, Weston SR, Pabst MS, Aouizerat BE, Bass NM: Correlation of paired liver biopsies in morbidly obese patients with suspected nonalcoholic fatty liver disease. Hepatology 2006, 44:874-80.

\section{FlOOOPrime}

\section{RECOMMENDED}

31. Ryan MC, Wilson AM, Slavin J, Best JD, Jenkins AJ, Desmond PV: Associations between liver histology and severity of the metabolic syndrome in subjects with nonalcoholic fatty liver disease. Diabetes Care 2005, 28: 1222-4.

\section{FlOOOPrime \\ RECOMMENDED}

32. Loomba R, Abraham M, Unalp A, Wilson L, Lavine J, Doo E, Bass NM, Nonalcoholic Steatohepatitis Clinical Research N: Association between diabetes, family history of diabetes, and risk of nonalcoholic steatohepatitis and fibrosis. Hepatology 2012, 56:943-5I.

\section{FlOOOPrime}

\section{RECOMMENDED}

33. Machado MV, Cortez-Pinto $\mathrm{H}$ : Non-invasive diagnosis of nonalcoholic fatty liver disease. A critical appraisal. J Hepatol 2013, 58:1007-19.

\section{FlOOOPrime}

\section{RECOMMENDED}

34. Diab DL, Yerian L, Schauer P, Kashyap SR, Lopez R, Hazen SL, Feldstein AE: Cytokeratin 18 fragment levels as a noninvasive biomarker for nonalcoholic steatohepatitis in bariatric surgery patients. Clin Gastroenterol Hepatol 2008, 6: 1249-54.

35. Tsutsui M, Tanaka N, Kawakubo M, Sheena Y, Horiuchi A, Komatsu M, Nagaya T, Joshita S, Umemura T, Ichijo T, Matsumoto A, Yoshizawa K, Aoyama T, Tanaka E, Sano K: Serum fragmented cytokeratin 18 levels reflect the histologic activity score of nonalcoholic fatty liver disease more accurately than serum alanine aminotransferase levels. J Clin Gastroenterol 2010, 44:440-7.

36. Wieckowska A, Zein NN, Yerian LM, Lopez AR, McCullough AJ Feldstein AE: In vivo assessment of liver cell apoptosis as a novel biomarker of disease severity in nonalcoholic fatty liver disease. Hepatology 2006, 44:27-33.

\section{FlOOOPrime}

37. Yilmaz Y, Dolar E, Ulukaya E, Akgoz S, Keskin M, Kiyici M, Aker S, Yilmaztepe A, Gurel S, Gulten M, Nak SG: Soluble forms of extracellular cytokeratin 18 may differentiate simple steatosis from nonalcoholic steatohepatitis. World J Gastroenterol 2007. 13:837-44.

38. Cusi K, Chang Z, Harrison S, Lomonaco R, Bril F, Orsak B, OrtizLopez C, Hecht J, Feldstein AE, Webb A, Louden C, Goros M, Tio F: Limited value of plasma cytokeratin- 18 as a biomarker for NASH and fibrosis in patients with non-alcoholic fatty liver disease. J Hepatol 20I4, 60:167-74.

\section{FlOOOPrime}

39. Musso G, Gambino R, Cassader M, Pagano G: Meta-analysis: natural history of non-alcoholic fatty liver disease (NAFLD) and diagnostic accuracy of non-invasive tests for liver disease severity. Ann Med 20II, 43:6I7-49.

\section{FlOOOPrime \\ RECOMMENDED}

40. Rosenberg WM, Voelker M, Thiel R, Becka M, Burt A, Schuppan D, Hubscher S, Roskams T, Pinzani M, Arthur MJ, European Liver Fibrosis Group: Serum markers detect the presence of liver fibrosis: a cohort study. Gastroenterology 2004, I 27:1704-13.

\section{FlOOOPrime} RECOMMENDED

4I. Yoneda M, Yoneda M, Fujita K, Inamori M, Tamano M, Hiriishi $H$, Nakajima A: Transient elastography in patients with nonalcoholic fatty liver disease (NAFLD). Gut 2007, 56: I330-I.

\section{FlOOOPrime \\ RECOMMENDED}

42. Wong VW, Vergniol J, Wong GL, Foucher J, Chan HL, Le Bail B, Choi PC, Kowo M, Chan AW, Merrouche W, Sung IJ, de Lédinghen V: Diagnosis of fibrosis and cirrhosis using liver stiffness measurement in nonalcoholic fatty liver disease. Hepatology 2010 5 I:454-62.

43. Friedrich-Rust M, Hadji-Hosseini H, Kriener S, Herrmann E, Sircar I, Kau A, Zeuzem S, Bojunga !: Transient elastography with a new probe for obese patients for non-invasive staging of nonalcoholic steatohepatitis. Eur Radiol 2010, 20:2390-6.

\section{FlOOOPrime}

\section{RECOMMENDED}

44. Yoneda M, Suzuki K, Kato S, Fujita K, Nozaki Y, Hosono K, Saito S, Nakajima A: Nonalcoholic fatty liver disease: US-based acoustic radiation force impulse elastography. Radiology 2010, 256:640-7.

\section{FlOOOPrime \\ RECOMMENDED}

45. Friedrich-Rust M, Romen D, Vermehren J, Kriener S, Sadet D, Herrmann E, Zeuzem S, Bojunga J: Acoustic radiation force impulse-imaging and transient elastography for non-invasive assessment of liver fibrosis and steatosis in NAFLD. Eur J Radiol 20I2, $81:$ e325-33|

\section{FlOOOPrime}

\section{RECOMMENDED}

46. Ebinuma $H$, Saito $H$, Komuta M, Ojiro K, Wakabayashi K, Usui $S$, Chu PS, Umeda R, Ishibashi Y, Takayama T, Kikuchi M, Nakamoto N, Yamagishi Y, Kanai T, Ohkuma K, Sakamoto M, Hibi T: Evaluation of liver fibrosis by transient elastography using acoustic radiation 
force impulse: comparison with Fibroscan((R)). / Gastroenterol 20II, 46: 1238-48.

\section{FlOOOPrime}

47. Bota S, Herkner H, Sporea I, Salzl P, Sirli R, Neghina AM, PeckRadosavljevic M: Meta-analysis: ARFI elastography versus transient elastography for the evaluation of liver fibrosis. Liver Int 2013, 33: I 138-47.

48. Yin M, Talwalkar JA, Glaser KJ, Manduca A, Grimm RC, Rossman PJ, Fidler JL, Ehman RL: Assessment of hepatic fibrosis with magnetic resonance elastography. Clin Gastroenterol Hepatol 2007, 5: $\mid 207-1213$ el 202.

\section{FlOOOPrime}

\section{RECOMMENDED}

49. Promrat K, Kleiner DE, Niemeier HM, Jackvony E, Kearns M, Wands JR, Fava JL, Wing RR: Randomized controlled trial testing the effects of weight loss on nonalcoholic steatohepatitis. Hepatology 2010 , $51:|2|-9$.

\section{FIOOOPrime}

50. Harrison SA, Fecht W, Brunt EM, Neuschwander-Tetri BA: Orlistat for overweight subjects with nonalcoholic steatohepatitis: A randomized, prospective trial. Hepatology 2009, 49:80-6.

\section{FlOOOPRime
RECOMMENDED}

5I. Johnson NA, Sachinwalla T, Walton DW, Smith K, Armstrong A, Thompson MW, George J: Aerobic exercise training reduces hepatic and visceral lipids in obese individuals without weight loss. Hepatology 2009, 50:1 105-12.

\section{FlOOOPrime} RECOMMENDED

52. Rafiq N, Bai C, Fang Y, Srishord M, McCullough A, Gramlich T, Younossi ZM: Long-term follow-up of patients with nonalcoholic fatty liver. Clin Gastroenterol Hepatol 2009, 7:234-8.

53. Marchesini G, Bugianesi E, Forlani G, Cerrelli F, Lenzi M, Manini R, Natale S, Vanni E, Villanova N, Melchionda N, Rizzetto M: Nonalcoholic fatty liver, steatohepatitis, and the metabolic syndrome. Hepatology 2003, 37:917-23.

54. Nguyen TA, Sanyal AJ: Pathophysiology guided treatment of nonalcoholic steatohepatitis. J Gastroenterol Hepatol 2012, 27 (Suppl 2):58-64.

55. Miyazaki H, Takitani K, Koh M, Yoden A, Tamai H: The alphatocopherol status and expression of alpha-tocopherol-related proteins in methionine-choline deficient rats treated with vitamin E. J Clin Biochem Nutr 2014, 54:190-7.

56. Pascoe GA, Fariss MW, Olafsdottir K, Reed DJ: A role of vitamin E in protection against cell injury. Maintenance of intracellular glutathione precursors and biosynthesis. Eur J Biochem 1987, 166:24I-7.

57. Zamin Jr I, Mattos AA, Mattos AZ, Coral G, Santos D, Rhoden C: The vitamin $E$ reduces liver lipoperoxidation and fibrosis in a model of nonalcoholic steatohepatitis. Arq Gastroenterol 2010, 47:86-92.

58. Chung MY, Yeung SF, Park HJ, Volek JS, Bruno RS: Dietary alpha- and gamma-tocopherol supplementation attenuates lipopolysaccharide-induced oxidative stress and inflammatory-related responses in an obese mouse model of nonalcoholic steatohepatitis. J Nutr Biochem 2010, 21:1200-6.

59. Sanyal AJ, Chalasani N, Kowdley KV, McCullough A, Diehl AM, Bass NM, Neuschwander-Tetri BA, Lavine JE, Tonascia J, Unalp A, Van Natta M, Clark J, Brunt EM, Kleiner DE, Hoofnagle JH, Robuck PR; NASH CRN: Pioglitazone, vitamin E, or placebo for nonalcoholic steatohepatitis. N Engl J Med 2010, 362:1675-85.

\section{FlOOOPrime} RECOMMENDED

60. Miller ER, 3rd, Pastor-Barriuso R, Dalal D, Riemersma RA, Appel LJ, Guallar E: Meta-analysis: high-dosage vitamin E supplementation may increase all-cause mortality. Ann Intern Med 2005, 142:37-46.
6I. Schurks M, Glynn RJ, Rist PM, Tzourio C, Kurth T: Effects of vitamin $E$ on stroke subtypes: meta-analysis of randomised controlled trials. BMJ 2010, $341: c 5702$

62. Klein EA, Thompson IM, Jr., Tangen CM, Crowley JJ, Lucia MS, Goodman PJ, Minasian LM, Ford LG, Parnes HL, Gaziano JM, Karp DD, Lieber MM, Walther PJ, Klotz L, Parsons JK, Chin JL, Darke AK, Lippman SM, Goodman GE, Meyskens FL Jr, Baker LH: Vitamin $E$ and the risk of prostate cancer: the Selenium and Vitamin E Cancer Prevention Trial (SELECT). JAMA 20II, 306:1549-56.

\section{FlOOOPrime

RECOMMENDED

63. Bajaj M, Suraamornkul S, Piper P, Hardies LJ, Glass L, Cersosimo E, Pratipanawatr T, Miyazaki Y, DeFronzo RA: Decreased plasma adiponectin concentrations are closely related to hepatic fat content and hepatic insulin resistance in pioglitazonetreated type 2 diabetic patients. J Clin Endocrinol Metab 2004, 89:200-6.

64. Coletta DK, Sriwijitkamol A, Wajcberg E, Tantiwong P, Li M, Prentki M, Madiraju M, Jenkinson CP, Cersosimo E, Musi N, Defronzo RA: Pioglitazone stimulates AMP-activated protein kinase signalling and increases the expression of genes involved in adiponectin signalling, mitochondrial function and fat oxidation in human skeletal muscle in vivo: a randomised trial. Diabetologia 2009, 52:723-32.

65. Belfort R, Harrison SA, Brown K, Darland C, Finch J, Hardies J, Balas B, Gastaldelli A, Tio F, Pulcini J, Berria R, Ma JZ, Dwivedi S, Havranek R, Fincke C, DeFronzo R, Bannayan GA, Schenker S, Cusi K: A placebocontrolled trial of pioglitazone in subjects with nonalcoholic steatohepatitis. N Engl J Med 2006, 355:2297-307.

\section{FlOOOPrime
RECOMMENDED}

66. Boettcher E, Csako G, Pucino F, Wesley R, Loomba R: Meta-analysis: pioglitazone improves liver histology and fibrosis in patients with non-alcoholic steatohepatitis. Aliment Pharmacol Ther 2012, 35:66-75.

\section{FlOOOPrime}

RECOMMENDED

67. Erdmann E, Charbonnel B, Wilcox RG, Skene AM, Massi-Benedetti M, Yates J, Tan M, Spanheimer R, Standl E, Dormandy JA, PROactive investigators: Pioglitazone use and heart failure in patients with type 2 diabetes and preexisting cardiovascular disease: data from the PROactive study (PROactive 08). Diabetes Care 2007, 30:2773-8.

68. Meier C, Kraenzlin ME, Bodmer M, Jick SS, Jick H, Meier CR: Use of thiazolidinediones and fracture risk. Arch Intern Med 2008, 168:820-5.

69. Lewis JD, Ferrara A, Peng T, Hedderson M, Bilker WB, Quesenberry CP, Jr., Vaughn DJ, Nessel L, Selby J, Strom BL: Risk of bladder cancer among diabetic patients treated with pioglitazone: interim report of a longitudinal cohort study. Diabetes Care 20II, 34:916-922.

70. Musso G, Gambino R, Cassader M, Pagano G: A meta-analysis of randomized trials for the treatment of nonalcoholic fatty liver disease. Hepatology 2010, 52:79-104.

7I. Cipriani S, Mencarelli A, Palladino G, Fiorucci S: FXR activation reverses insulin resistance and lipid abnormalities and protects against liver steatosis in Zucker (fa/fa) obese rats. J Lipid Res 2010, 51:77|-84.

\section{FlOOOPrime}

\section{RECOMMENDED}

72. Fickert P, Fuchsbichler A, Moustafa T, Wagner M, Zollner G, Halilbasic E, Stoger U, Arrese M, Pizarro M, Solis N, Carrasco G, Caligiuri A, Sombetzki M, Reisinger E, Tsybrovskyy O, Zatloukal K, Denk H, Jaeschke H, Pinzani M, Trauner M: Farnesoid X receptor critically determines the fibrotic response in mice but is 
expressed to a low extent in human hepatic stellate cells and periductal myofibroblasts. Am J Pathol 2009, I75:2392-405.

\section{FlOOOPrime}

73. Verbeke L, Farre R, Trebicka J, Komuta M, Roskams T, Klein S, Elst IV, Windmolders P, Vanuytsel T, Nevens F, Laleman W: Obeticholic acid, a farnesoid $X$ receptor agonist, improves portal hypertension by two distinct pathways in cirrhotic rats. Hepatology 2014, 59:2286-98.
74. Neuschwander-Tetri BA, Loomba R, Sanyal AJ, Lavine JE, Van Natta ML, Abdelmalek MF, Chalasani N, Dasarathy S, Diehl AM, Hameed B, Kowdley KV, McCullough A, Terrault N, Clark JM, Tonascia J, Brunt EM, Kleiner DE, Doo E; for the NASH Clinical Research Network: Farnesoid $\mathbf{X}$ nuclear receptor ligand obeticholic acid for non-cirrhotic, non-alcoholic steatohepatitis (FLINT): a multicentre, randomised, placebo-controlled trial. Lancet 2014. [Epub ahead of print] - A large trial on obeticholic in NAFLD. 